\title{
Abrupt Climate Change: Time is tight
}

\author{
Jan-Erik Lane \\ Professor Emeritus at UNIGE, Switzerland
}

\begin{abstract}
The new theme of abrupt climate change ("Hawking tipping point") must be taken up by global coordination - the UNFCCC, IPCC and the G20. The only policy response is to reinforce the COP21 project, and start managing its quick implementation of decarbonisation. A more decisive climate change policy - no coal or charcoal, solar power parks, and possibly carbon capture - may not guarantee the goal of +2 degrees Celsius, but it may help avoid climate chaos. Only global coordination can break through the resistance of markets in the rich countries and governments in the Third World together with vibrant civil society. The large COP21 Secretariat must become a management agency for rapid decarbonisation with support from other global bodies (WB, IMF) and the G20.
\end{abstract}

Keywords: abrupt climate change, Arctic ice meltdown, methane emissions from permafrost, positive feedback lopes. Hawking tipping point

\section{INTRODUCTION}

Climate and earth scientists have convinced a large majority of people that climate change occurs today. And the new theory of abrupt climate change entails that huge feedback lopes will change the Earth already within the next one or two decades. It is a matter of Arctic ice meltdown and methane emissions from the permafrost that may bring temperatures much higher than the COP21 Treaty aimed at with uncertain disastrous consequences for both Mother Earth and mankind. Lots of natural science research still remains to be done in order to reduce the large uncertainties about temperature rise and its consequences for a number of vital outcomes for humanity.

Yet, this information is only half the story, as the pragmatical side is also part of climate change: will the COP21 promise of global decarbonisation be fulfilled? It requires global coordination by states or government, which is very hard to achieve. The COP process by the UNFCCC and the IPCC never speaks about it. The aim of this paper is to emphasize that global deecarbonisation can only be accomplished by global state coordination, which reduces the probability of COP21 success considerably.

\section{POLITICAL ECONOMY OF ENERGY}

Political economy is the social science interdisciplinary study of the interaction between markets and governments in determining poverty or affluence, democracy or dictatorship and war or peace. The political economy sources of global warming as driven by energy consumption of fossil fuels involves:

1) Market search for affluence and bypass climate change;

2) Government struggles against poverty and fear social upheaval.

\section{Markets: Affluence, Economic Growth and Enormous Energy Need}

The market economy operates according to the logic of J.B. Say: supply determines demand. The firm aims to produce as much as possible at the lowest cost, making the enterprise profitable for its three interests - owners, managers and workers. Ideally, it is on a sustainable growth path over time, but it requires access to energy. 
Energy shows up in every sector of the economy in a broad sense, from transportation, industry, households and agriculture as well as electricity - see Figure with attending GHG emissions.

Figure 1. Energy, sectors and GHGs globally

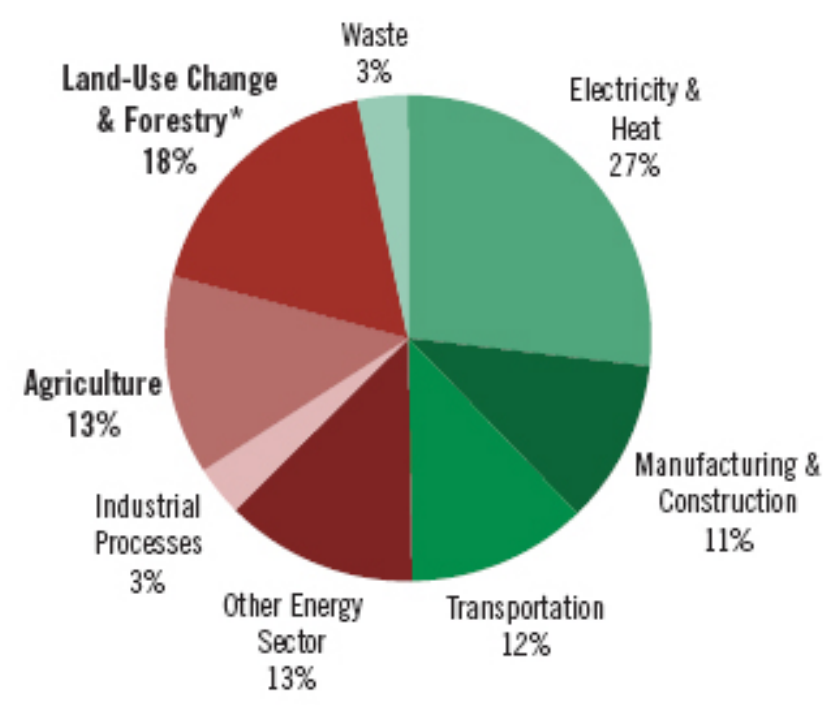

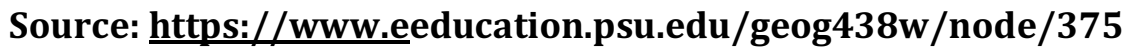

In rich countries with an economy in balance more or less, domestically and internationally, the Say perspective upon economic motivations entails the idea of balanced economic growth, supported strongly by financial markets. Even if real economic growth fluctuates, the emphasis upon yearly economic growth is typical of capitalism or the market economy, but so far it has necessitated a constant augmentation of energy. Figure 2 shows the tight relation between affluence and energy.

Figure 2. Affuence and energy 1990-2016

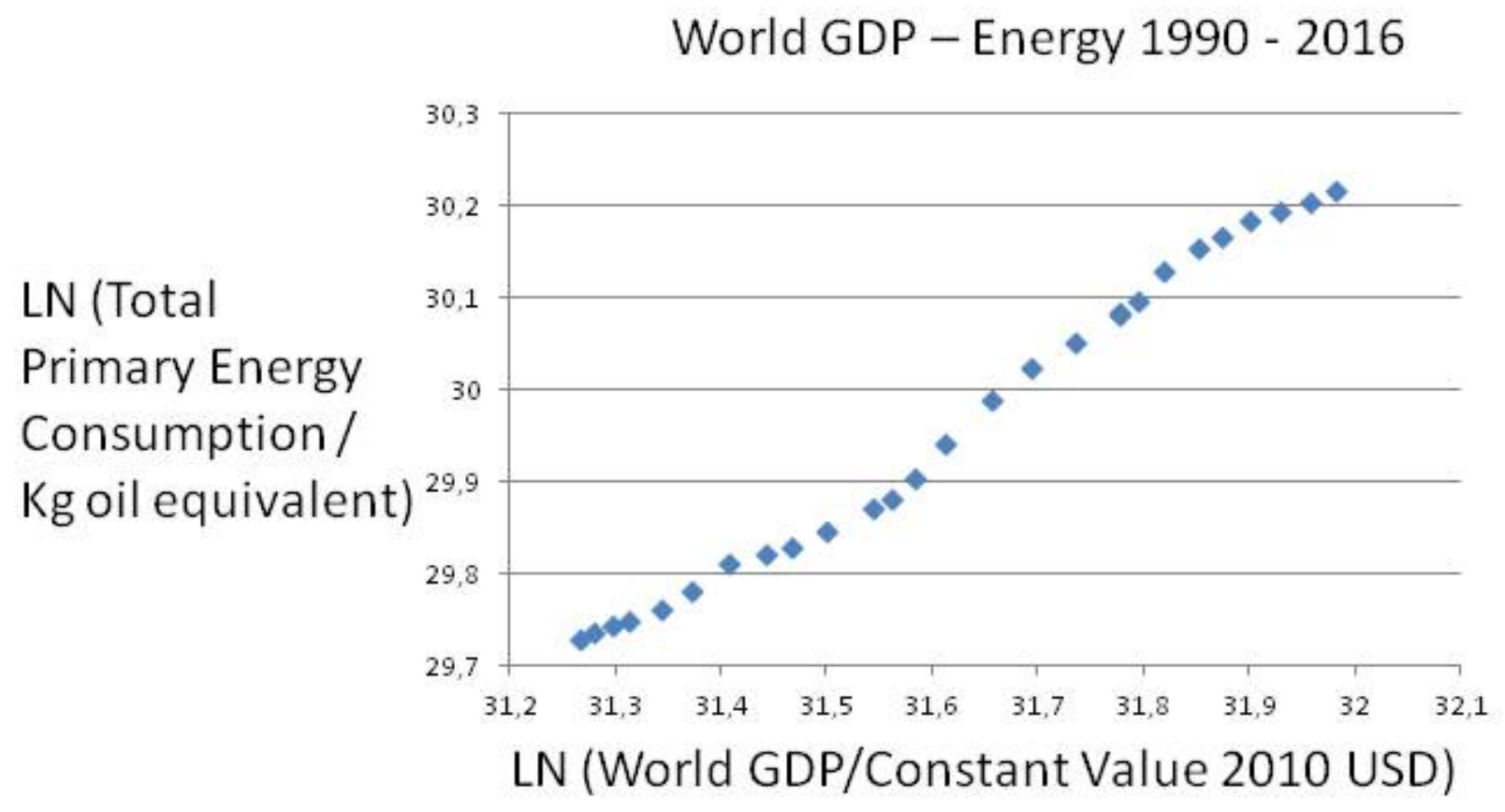


The market players would of course want this trend to just go on. But the attending CO2s call for major change (Figure 3) that markets may resist or underestimate or simply try to postpone. Figure 3 shows the global connection between energy consumption and $\mathrm{CO} 2$ emissions.

Figure 3. Energy and C02:s: $y=1,01 x ; R^{2}=0,99$

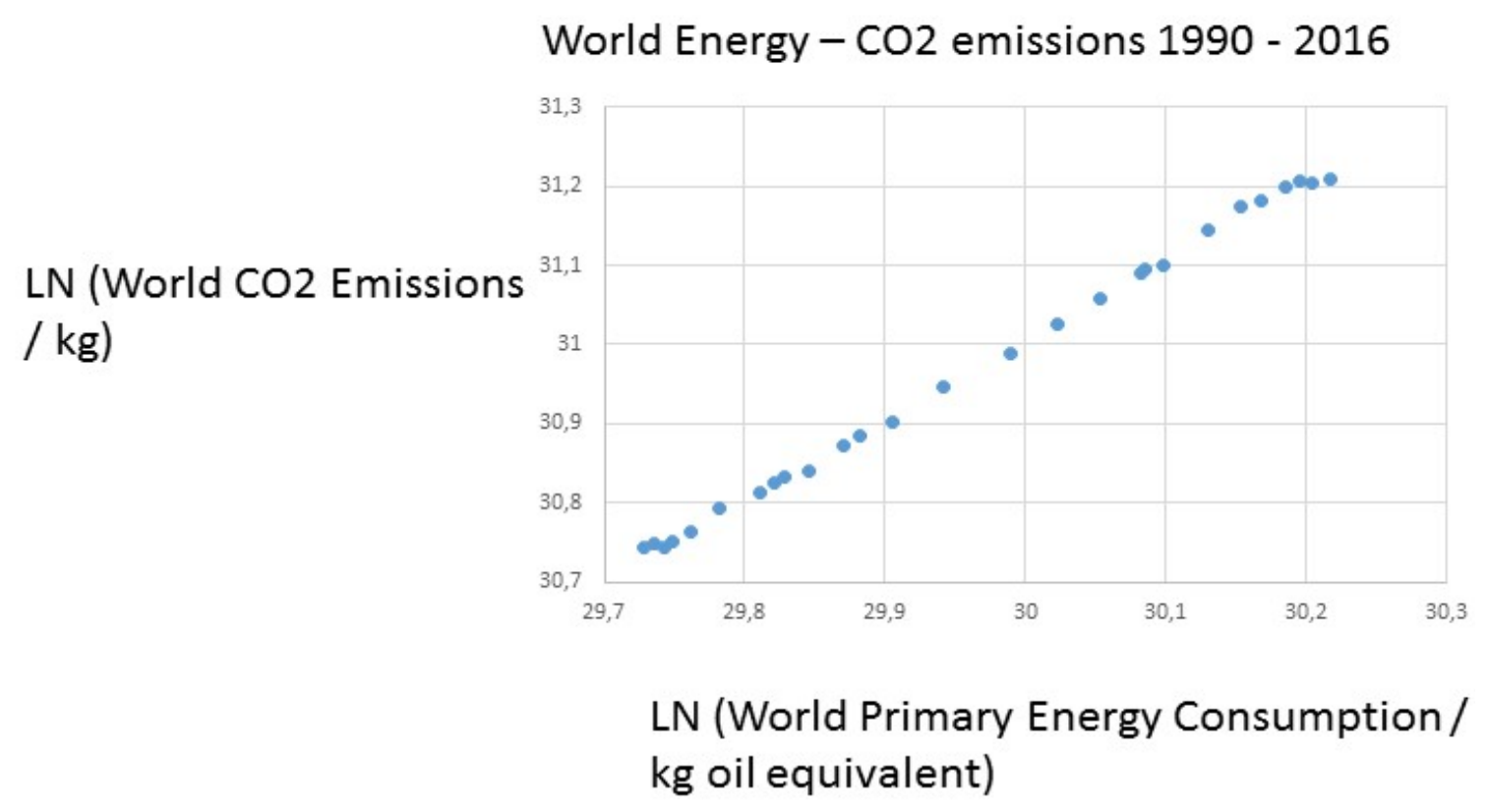

Source: BP Statistical Review of World Energy 2017, http://www.bp.com/statisticalreview; Janssens-Maenhout, G., Crippa, M., Guizzardi, D., Muntean, M., Schaaf, E., Olivier, J.G.J., Peters, J.A.H.W., Schure, K.M., Fossil CO2 and GHG emissions of all world countries, EUR 28766 EN, Publications Office of the European Union, Luxembourg, 2017, ISBN 978-92-79-73207-2, doi:10.2760/709792, JRC107877

Markets have not yet fully anticipated the enormous costs of abrupt climate change. Production must be forthcoming that uses less energy and other energy resources, i.e. renewables. Business as usual make cover innovations like electrical cars, solar and wind energy and improved atomic power, but the size of fossil fuel energy remains much too large. Hating uncertainty, markets are in general favourable to the established energy plans.

The resistance of organised interests and financial institutions towards radical energy policies is understandable when one takes into account the market commitment to steady economic growth. The fear is depression - too little of Say's production with unemployment and falling demand. Some political parties in advanced democracies are very sensitive to economic decline not hesitation to favour fossil fuel energy extraction.

\section{Government: Fear of Massive Instability, Poverty and Energy Lack}

Most people in the world live in the so-called Third World where poverty and social unrest results in political instability. Politicians know that the must deliver on promises to improve living conditions or face elimination somehow. Access to cheap energy is vital, meaning fossil fuels, especially coal and charcoal.

The living conditions in the poor countries in Latin America, Africa and Asia as well as the Pacific reflects the low level of energy employed. This basic fact determines life opportunities 
in a most dramatic fashion. The low access to energy has consequences for the environment and the life situation of people, including health, schooling, work, food and potable water.

African countries are poor because they have too little energy. Thus, they have much less GHGs than Asia. Yet, they need the COP project of the UNFCCC to renew their energy sources and move from fossil fuels and traditional renewables to solar power. Hydro power depends upon water availability that shrinks with global warming.

African energy deficit is conducive to a dire environment with enormous damages and risks. Consider the following global figures. Figure 4 shows how low energy leads to am unsafe environmental.

Figure 4: Energy and environmental risk exposure

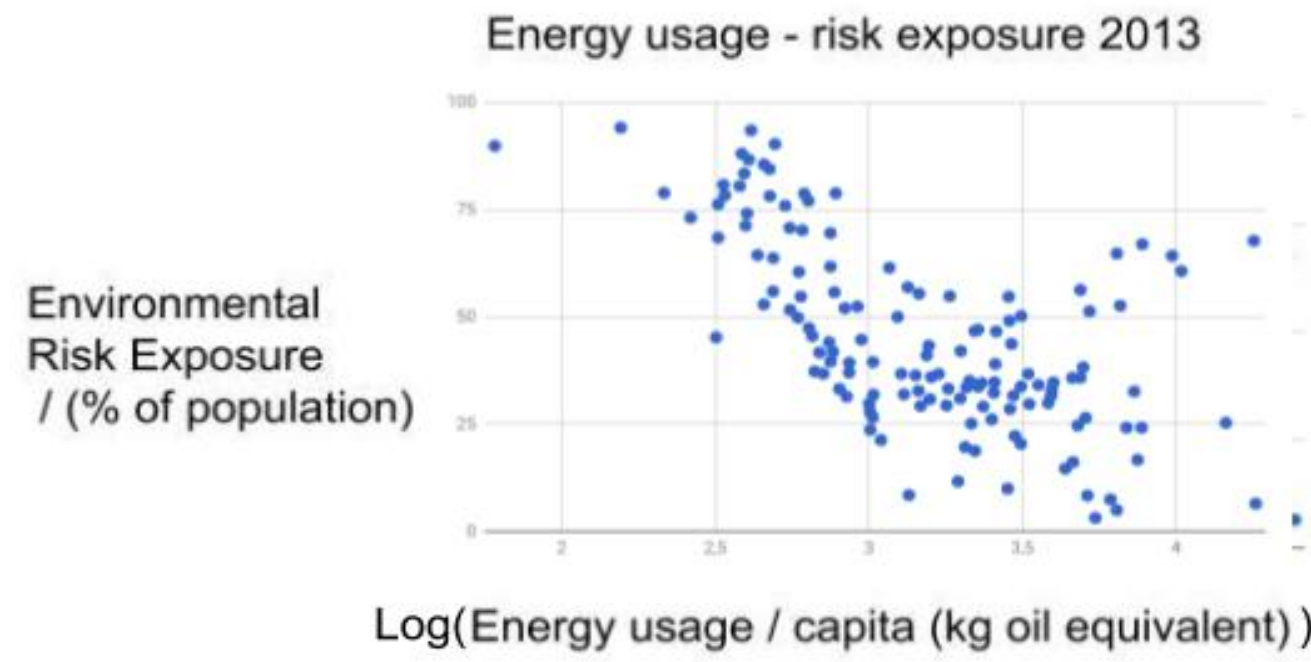

\section{Source: Environmental Performance Index, Yale University, https://epi.envirocenter.yale. IEA Statistics (C) OECD/IEA 2014 (http://www.iea.org/stats/inde}

Low energy use leads to poverty, malnutrition, deceases, lack of potable water, insufficient sanitation, etc. Typical of many Latin American, African and Asian nations is the lack of stable electricity, which hampers everything and reduces environmental viability. Figure 5 has the global picture. 
Figure 5. Energy and electricity access

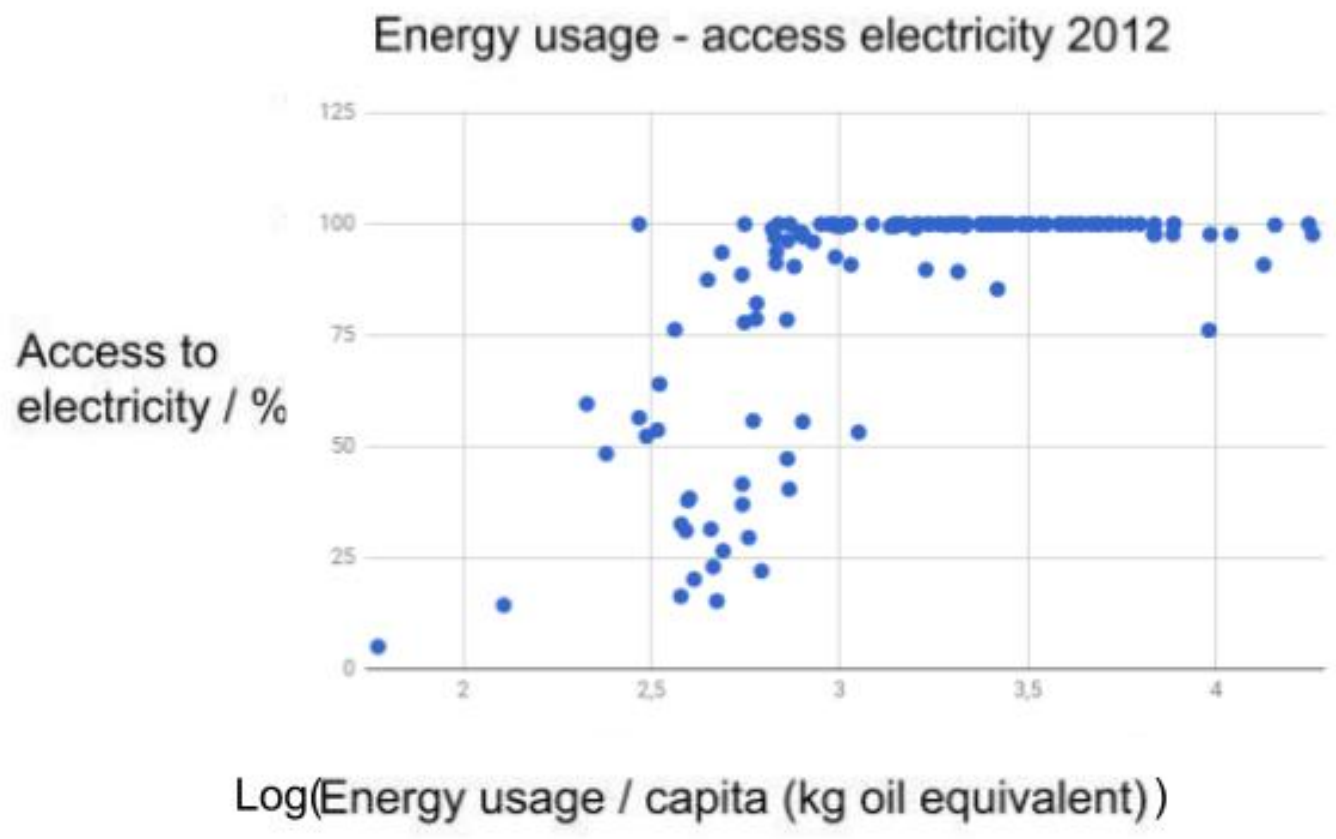

Source: Environmental Performance Index, Yale University, https://epi.envirocenter.yale. IEA Statistics @ OECD/IEA 2014 (http://www.iea.org/stats/inde

The access to safe and stable electricity is crucial for health, schools, food, water, etc. Figure 6 links energy with proper sanitation.

Figure 6. Sanitation and energy
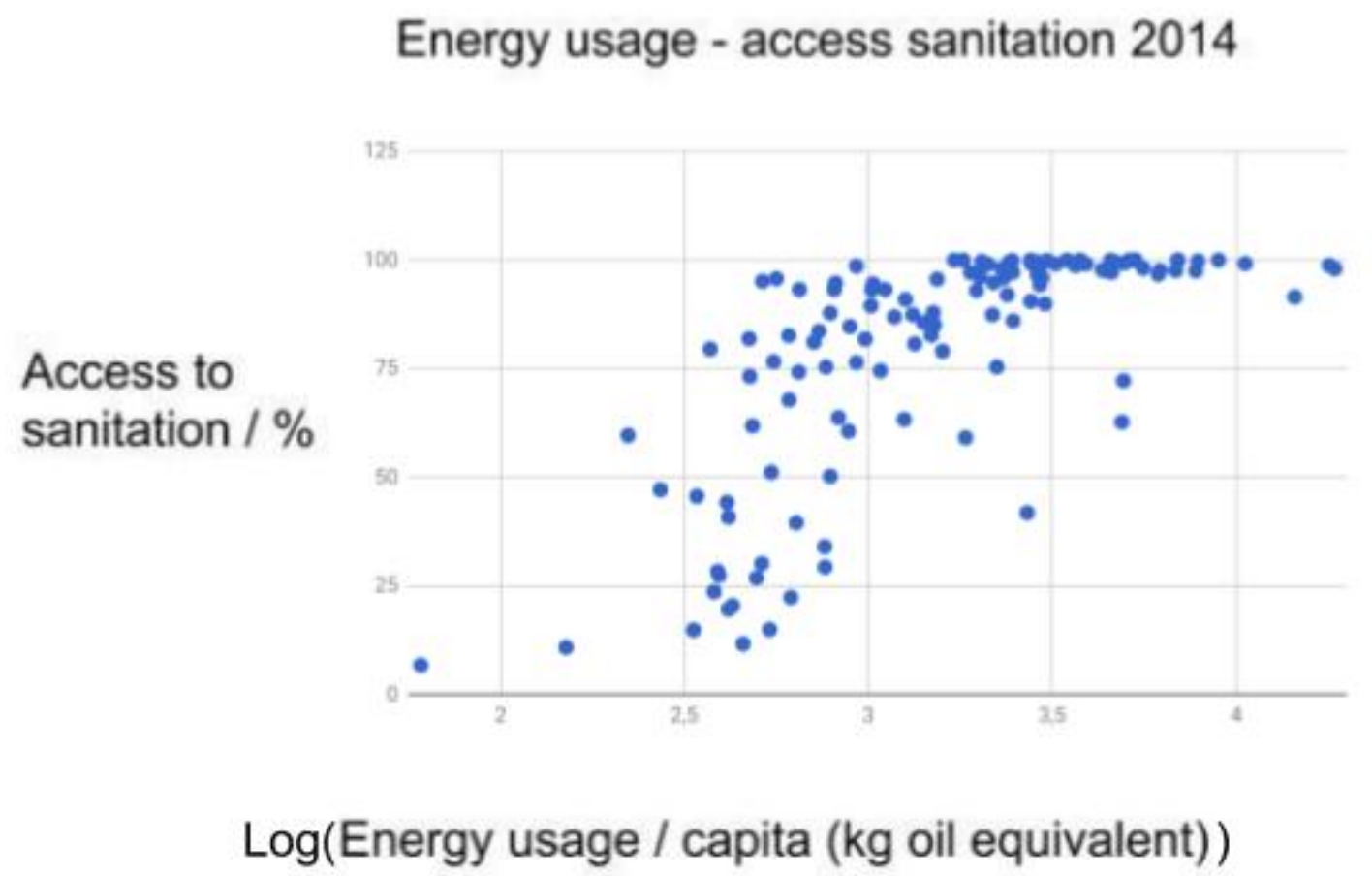

Source: Environmental Performance Index, Yale University, https://epi.envirocenter.yale. IEA Statistics @ OECD/IEA 2014 (http://www.iea.org/stats/index) 
Especially, the rapidly growing African and Asian mega-cities lack entirely sewage plants. Thus, dirty water is put into the big rivers where other cities downstream take their potable water.

The access to safe and stable electricity is crucial for health, schools, food, water, etc.

Figure 7 links energy with proper sanitation.

Figure 7. Sanitation and energy

\section{Energy usage - access sanitation 2014}

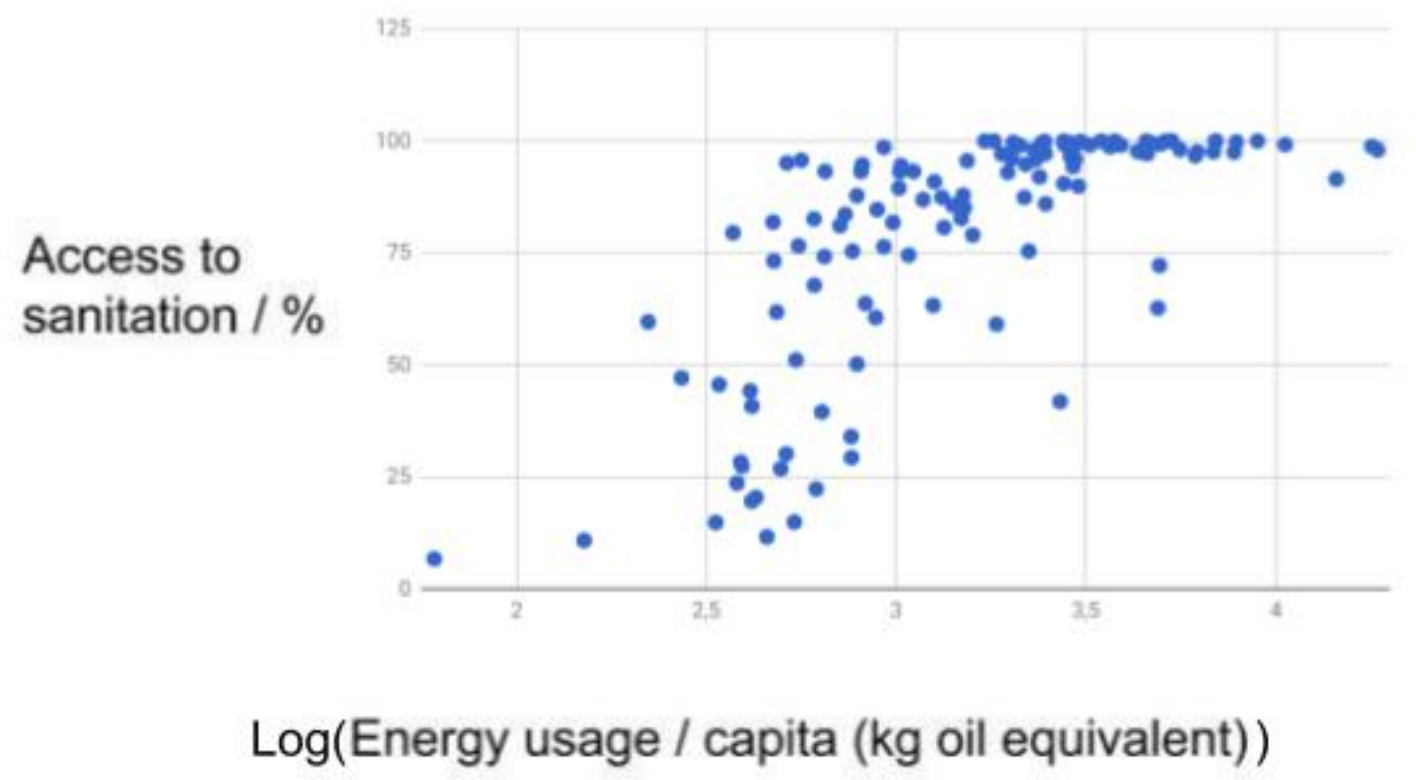

Source: Environmental Performance Index, Yale University, https://epi.envirocenter.yale. IEA Statistics C) OECD/IEA 2014 (http://www.iea.org/stats/inde

Figure 8 underscores the necessity of more energy in poor coutries.

Figure 8. Energy and unsafe sanitation
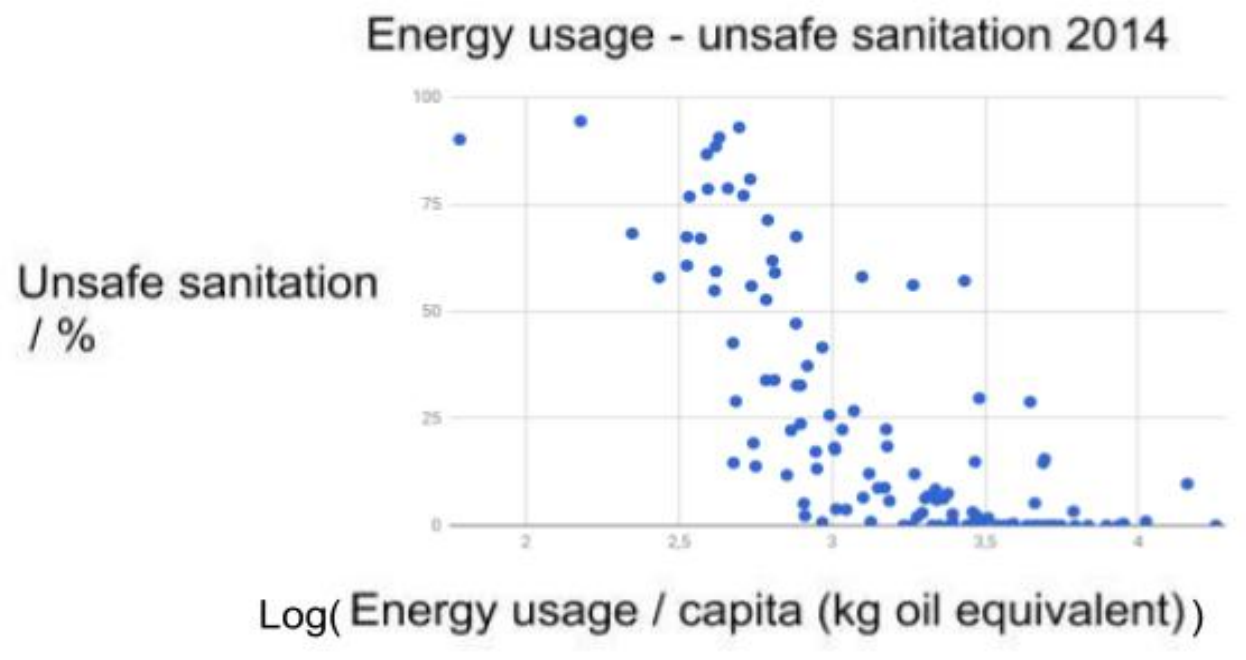

Source: Environmental Performance Index, Yale University, https://epi.envirocenter.yale. IEA Statistics @ OECD/IEA 2014 (http://www.iea.org/stats/inde 
Air quality too depends upon energy access (Figure 9).

Figure 9. Energy and air quality

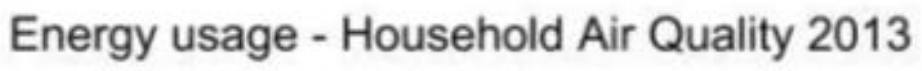

Household Air Quality Index

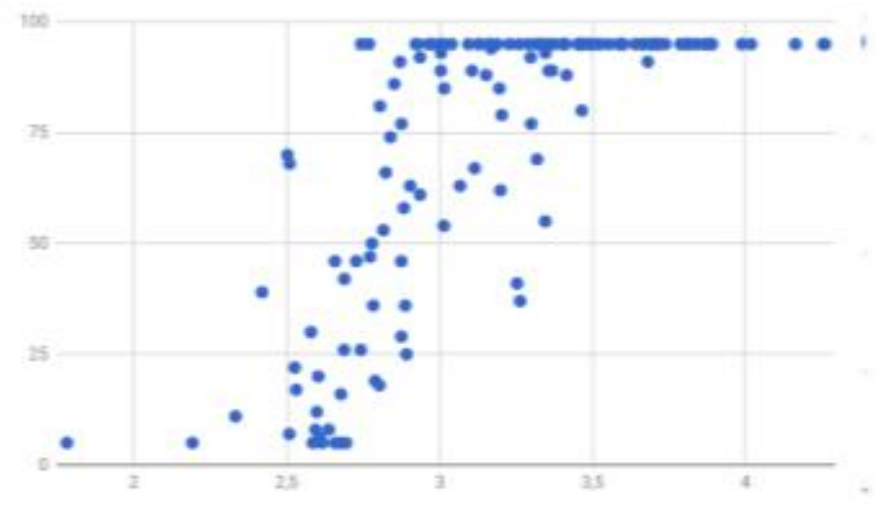

\section{Log(Energy usage / capita ( $\mathrm{kg}$ oil equivalent))}

\section{Source: Environmental Performance Index, Yale University, https://epi.envirocenter.yale. IEA Statistics @ OECD/IEA 2014 (http://www.iea.org/stats/inde}

Typical of many poor nations - Latin America, Africa, Asia - is the lack of stable electricity, which hampers work and reduces environmental viability. The access to safe electricity is crucial for health, schools, food, water, etc. Given the lack of enough energy in poor countries being conducive to the above bad living conditions, one understands the hopes of the poor countries for help with energy transformation leading to better access to just energy!

Governments in the third world would line to have an assurance that the global COP21 project of decarbonisation does not lead to less energy or more expensive energy for them. Otherwise, governments may face social upheaval.

\section{ABRUPT CLIMATE CHANGE: UPGRADE COP21}

The UNFCCC and the IPCC have been surprised by the force of abrupt climate change. Its chief objective of limiting global warming to +2 degrees Celsius is hardly relevant any longer. Thus, its policies are also out of date namely:

a) stop the increase in CO2s by 2020;

b) reduce CO2s by some $30 \%$ by 2030 (absolutely of relatively?);

c) full decarbonisation by 2075 .

Abrupt climate change alters the Keeling curve by projecting quicker temperature increases due to two dismal feedback lopes. First, we have the Arctic meltdown that will for a jump in temperature. Second, thee is the melting Permafrost with all its methane, conducive to climate chaos. No knows really how the objective +2 degrees Celsius was arrived upon in COP21, but with abrupt climate change temperatures will likely go pass this limit already in 10-20 years.

To reduce the impact of positive feedback loops, the COP21 must sharpen its policy tools, reducing the $\mathrm{CO} 2 \mathrm{~s}$ quicker. If climate change accelerates as with abrupt global warming and its dismal feedback, the global coordination by the UNFCCC and IPCC should also change speed. The COP21 project should be implemented with more strength and efficiency

1) Close down all coal everywhere and charcoal in poor countries (deforestation);

2) Start building giant solar power parks everywhere; 
3) Find out if geo-engineering works on a large scale, like e.g. carbon capture.

There measures will NOT aggravate the situation, but only help, at least to some extent. Why then is global coordination so slow?

The solar power revolution allows a massive reduction in fossil fuels. Let us see in Table 1 what it entails in terms of management tasks for global coordination, assisted by for instance the COP21 Secretariat and the IPCC.

Table 1. Number of Ouarzazate plants for 40 per cent reduction of $\mathrm{CO} 2$ in some giant countries (Note: Average of 250 - 300 days of sunshine used for all entries except Australia, Indonesia, and Mexico, where 300 - 350 was used).

\begin{tabular}{|c|c|c|c|}
\hline Nation & $\begin{array}{c}\text { Co2 reduction } \\
\text { pledge / } \\
\text { \% of 2005 emissions }\end{array}$ & $\begin{array}{c}\text { Number of gigantic } \\
\text { solar plants needed } \\
\text { (Ouarzazate) }\end{array}$ & $\begin{array}{c}\text { Gigantic plants } \\
\text { needed for 40 \% } \\
\text { reduction }\end{array}$ \\
\hline United States & $26-28^{\mathrm{i}}$ & 2100 & 3200 \\
\hline China & Noneii $\mathrm{i}^{\mathrm{ii}}$ & 0 & 3300 \\
\hline EU28 & $41-42$ & 2300 & 2300 \\
\hline India & none $\mathrm{e}^{\mathrm{ii}}$ & 0 & 600 \\
\hline Japan & 26 & 460 & 700 \\
\hline Brazil & 43 & 180 & 170 \\
\hline Indonesia & 29 & 120 & 170 \\
\hline Australia & $26-28$ & 130 & 190 \\
\hline Russia & None & 0 & 940 \\
\hline World & $\mathrm{N} / \mathrm{A}$ & $\mathrm{N} / \mathrm{A}$ & 16000 \\
\hline & & & \\
\hline & & & \\
\hline
\end{tabular}

Note: i)The United States has pulled out of the deal; ii) No absolute target; iii) Pledge is above current level, no reduction; iv) Upper limit dependent on receiving financial support; v) EU joint pledge of $40 \%$ compared to 1990.

It will of course be argued against such a 40 per cent speedy reuction in CO2s that it leads to economic recession. So may it be! But it would reduce future much higher costs. After all, economies adapt and will recover due to all new investments needed in a decarbonised world. Ramesh (2015) emphasizes that India needs much eonomic assistance for decarbonisation - a giant task for global coordination to assist poor nations!

Let us look at the American scene in Table 2.

Table 2. Number of Ouarzazate plants necessary for 40 per cent reduction in CO2 (Note: Average of 250 - 300 days of sunshine per year was used for Canada, 300 - 350 for the others). 


\begin{tabular}{|c|c|c|c|}
\hline Nation & $\begin{array}{c}\text { Co2 reduction } \\
\text { pledge / } \\
\text { \% of 2005 emissions }\end{array}$ & $\begin{array}{c}\text { Number of gigantic } \\
\text { solar plants needed } \\
\text { (Ouarzazate) }\end{array}$ & $\begin{array}{c}\text { Gigantic plants } \\
\text { needed for 40 \% } \\
\text { reduction }\end{array}$ \\
\hline Canada & 30 & 230 & 300 \\
\hline Mexico & 25 & 120 & 200 \\
\hline Argentina & none & 0 & 80 \\
\hline Peru & none & 0 & 15 \\
\hline Uruguay & none $\mathrm{e}^{\mathrm{ii}}$ & 0 & 3 \\
\hline Chile & 35 & 25 & 30 \\
\hline
\end{tabular}

Note: i)The United States has pulled out of the deal; ii) No absolute target; iii) Pledge is above current level, no reduction; iv) Upper limit dependent on receiving financial support; v) EU joint pledge of $40 \%$ compared to 1990.

Some Latin American countries have lots of hydro power, but it may dwindle rapidly due to abrupt climate change. Solar power would be excellent energy for Mexico and Brazil for example. Table 3 has the data for the African scene with a few key countries, poor or medium income. As they are not in general energy consuming on a grand scale, like Asia, decarbonisation should be feasible with Super Fund support.

Table 3. Number of Ouarzazate plants necessary in 2030 for 40 per cent reduction in CO2 (Note: Average of 300 - 350 days of sunshine per year was used).

\begin{tabular}{|c|c|c|c|}
\hline Nation & $\begin{array}{c}\text { Co2 reduction } \\
\text { pledge / } \\
\text { \% of 2005 emissions }\end{array}$ & $\begin{array}{c}\text { Number of gigantic } \\
\text { solar plants needed } \\
\text { (Ouarzazate) }\end{array}$ & $\begin{array}{c}\text { Gigantic plants } \\
\text { needed for 40 \% } \\
\text { reduction }\end{array}$ \\
\hline Algeria & $7-22^{\text {iv }}$ & 8 & 50 \\
\hline Egypt & none ii $^{\text {ii }}$ & 0 & 80 \\
\hline Senegal & $5-21$ & 0,3 & 3 \\
\hline Ivory Coast & $28-36^{\text {iv }}$ & 2 & 3 \\
\hline Ghana & $15-45^{\text {iv }}$ & 1 & 3 \\
\hline Angola & $35-50^{\text {iv }}$ & 6 & 7 \\
\hline Kenya & $30^{\text {iv }}$ & 3 & 4 \\
\hline Botswana & $17^{\text {iv }}$ & 1 & 1 \\
\hline Zambia & $25-47^{\text {iv }}$ & 0,7 & 190 \\
\hline South Africa & none & 0 & 2 \\
\hline
\end{tabular}

Note: i) The United States has pulled out of the deal; ii) No absolute target; iii) Pledge is above current level, no reduction; iv) Upper limit dependent on receiving financial support; v) EU joint pledge of $40 \%$ compared to 1990 .

Table 4 shows the number of huge solar parks necessary for a few Asian countries.

Table 4. Number of Ouarzazate plants necessary for 40 per cent reduction in CO2s. (Note: Average of 250 - 300 days of sunshine was used for Kazakhstan, 300 - 350 days of sunshine per year for the others). 


\begin{tabular}{|c|c|c|c|}
\hline Nation & $\begin{array}{c}\text { Co2 reduction } \\
\text { pledge / } \\
\text { \% of 2005 emissions }\end{array}$ & $\begin{array}{c}\text { Number of gigantic } \\
\text { solar plants needed } \\
\text { (Ouarzazate) }\end{array}$ & $\begin{array}{c}\text { Gigantic plants } \\
\text { needed for 40 \% } \\
\text { reduction }\end{array}$ \\
\hline Saudi Arabia & none $\mathrm{e}^{\mathrm{ii}}$ & 0 & 150 \\
\hline Iran & $4-12^{\mathrm{iv}}$ & 22 & 220 \\
\hline Kazakhstan & none & 0 & 100 \\
\hline Turkey & 21 & 60 & 120 \\
\hline Thailand & $20-25^{\mathrm{iv}}$ & 50 & 110 \\
\hline Malaysia & none $\mathrm{e}^{\mathrm{ii}}$ & 0 & 80 \\
\hline Pakistan & none $\mathrm{e}^{\mathrm{ii}}$ & 0 & 60 \\
\hline Bangladesh & 3,45 & 2 & 18 \\
\hline
\end{tabular}

Note:: i) The United States has pulled out of the deal; ii) No absolute target; iii) Pledge is above current level, no reduction; iv) Upper limit dependent on receiving financial support; v) EU joint pledge of $40 \%$ compared to 1990.

Given the economic advances in Asia, most countries need a lot of solar power parks for decarbonisation. The COP21 management would be able to help.

Finally, we come to the European scene.

Table 5. Number of Ouarzazate plants necessary for 40 per cent reduction in CO2s (Note: Average of 250 - 300 days of sunshine per year was used)

\begin{tabular}{|c|c|c|c|}
\hline Nation & $\begin{array}{c}\text { Co2 reduction } \\
\text { pledge / } \\
\text { \% of 2005 emissions }\end{array}$ & $\begin{array}{c}\text { Number of gigantic } \\
\text { solar plants needed } \\
\text { (Ouarzazate) }\end{array}$ & $\begin{array}{c}\text { Gigantic plants } \\
\text { needed for 40 \% } \\
\text { reduction }\end{array}$ \\
\hline Germany & $49^{\mathrm{v}}$ & 550 & 450 \\
\hline France & $37^{\mathrm{v}}$ & 210 & 220 \\
\hline Italy & $35^{\mathrm{v}}$ & 230 & 270 \\
\hline Sweden & $42^{\mathrm{v}}$ & 30 & 30 \\
\hline
\end{tabular}

Note: i)The United States has pulled out of the deal; ii) No absolute target; iii) Pledge is above current level, no reduction; iv) Upper limit dependent on receiving financial support; v) EU joint pledge of $40 \%$ compared to 1990.

\section{CARBON CAPTURE AND GEO-ENGINEERING}

Many scientists put their hope with carbon capture or carbon sequestration. There are various methods but they all aim at eliminating CO2s by hiding them under ground, either ex ante production or ex post production. Experiments on a small scale indicate it can be done, but costs are high. Whether it can be done on a massive scale is uncertain. The basic problem is to make sure CO2s stay put in the Earth's crest. If it is released again into the atmosphere, all is in vain.

Several proposals of geo-engineering have been launched in order to cool the Earth somehow using aerosols being one example. However, the side effects of geo-engineering techniques are not fully known, which poses tremendous risks for mankind More research on geo-engineering is vital and urgent. Can the COP21 secretariat and IPCC coordinate and assist various efforts at country geo-engineering?

Reducing CO2s for ever by solar power parks appear easier than carbon capture or geoenginering, but both types of policies can be helpful together. 


\section{COUNTRY PLANNING: ELIMINATION OF COAL AND CHARCOAL?}

The quickest and most effective way to jump start global decarbonisation is to simply take our all coal power stations and all charcoal use out. It would send the most powerful signal that the decarbonistion era has begun. Countries would find alternative energy resources in a short time, especially if aided by the COP21 project. Some countries may turn to natural gas and others to renewables!

Now, what would a total coal ban mean for the giant polluters of C02? Can they handle than in a time of abrupt climate change? There is no "WE" in climate policy-making, because all plicies must be decided by te governments of the states of the world, using unanimity in globsl coordination boards like the UNFCCC or G20. Thre is always the exit option - defection. Each governments decision the basis of its energy situation which varies much from country to county. Understanding global warming, one must look at the energy predicament of each nation.

\section{India}

In Indian energy policies, it is emphasized that developmental goals take precedence over climate change considerations. Thus, all Indian household musst have access to electricity and only sustained rapid economic growth can reduce poverty. India has a "take-off" economy that delivers affluence for the first time since independence. But it is based on fossil fuels. India looks into other sources of energy, as long as socio-economic development is not hindered. Figure 8 shows the main features of future planning.

Figure 10. India`s energy future

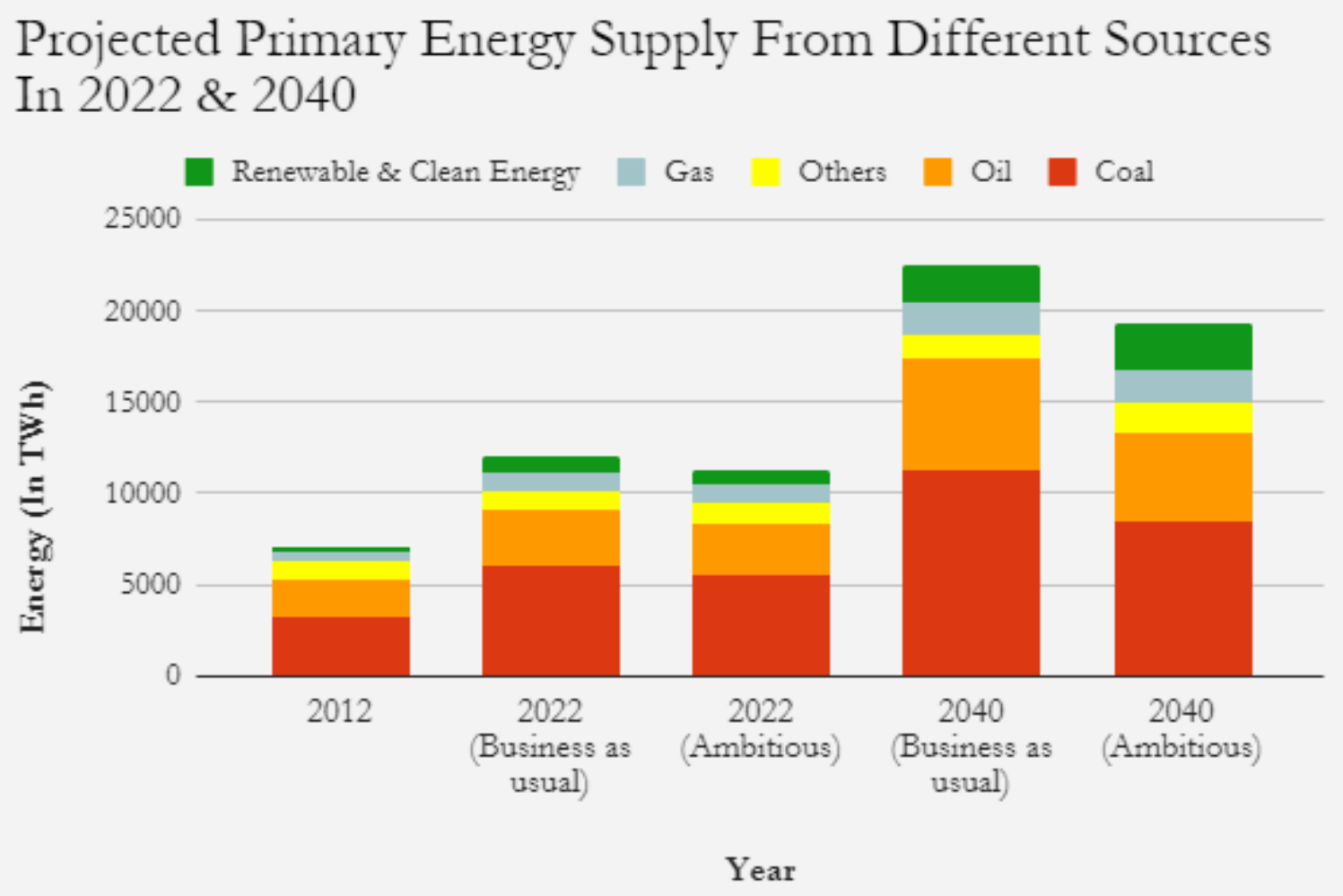

Source: https://scroll.in/article/843981/indias-new-energy-policy-draft-projects-coal-firedcapacity-will-double-by-2040-is-that-feasible

India has rapidly become a major CO2 emitter due to its high growth rates since 1990. It uses lots of coal, stone or wood. Charcoal is bad for households and results in forest destruction. 
India tries to broaaden its energy supply to modern renewables, like solar, wind and hydro power. Yet, it will remain stuck with fossil fuels for decades. It needs assistance from the COP21 project, especially for solar power parks. Building more dams is very risky, as global warming reduces water assets. Figure 10 indicates tthat India cannot meet its COP21 promises, as Ramesh (2015) has underlines.

\section{Brazil}

Brazil is a "catch-up" with its "take-off" point long ago in the $20^{\text {th }}$ century.. Compared with India, but it never really succeeds to close the gap to North America, tumbling now and then into dictatorship or recession. Figure 11 shows its stylised energy plans - are they in agreement with COP21 hopes of decarbonisaton?

Figure 11. Energy plans in Brazil

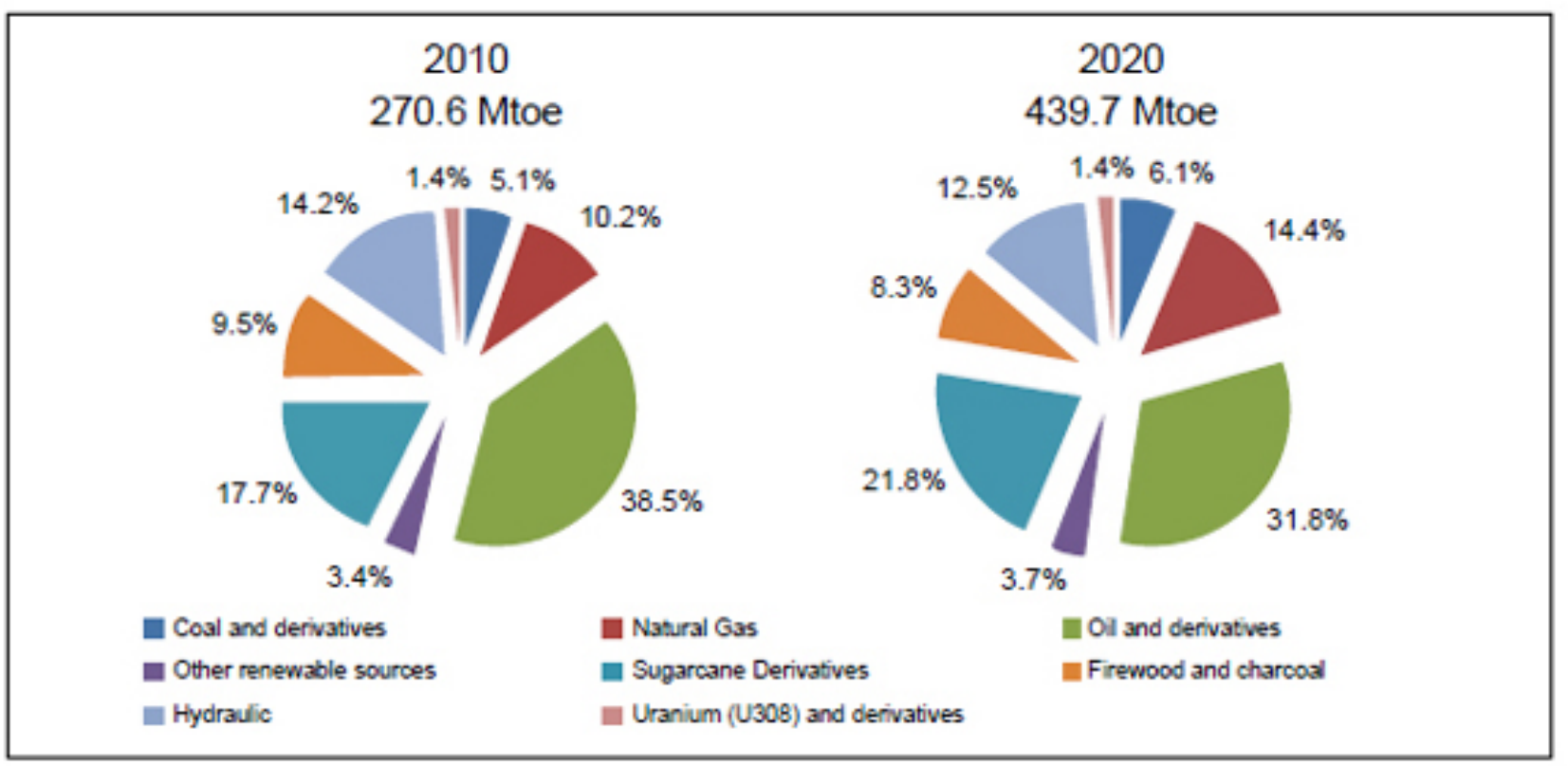

Figurel-Evolution of the total primary energy supply

\section{Source: http://www.scielo.br/scielo.php?pid=S0103- $40142012000100017 \&$ script=sci_arttext\&tlng=en}

Brazil has already a diversified supply of energy. However, since the country plans to almost double its energy supply, its dependence upon fossil fuel will grow, also upon coal. It dreams about building many more dams in the Amazons, but future water shortages due to climate change may make these plans unrealistic. The country needs COP21 assistance to turn to solar power massively, in order to eliminate first and foremost coal and charcoal. The rain forest is part of Brazil' s emission picture where burning and logging reduce its carbon uptake.

\section{Indonesia}

Indonesia is like India a "takee-off" country, enjoying rapid economic growth with attending augmentation in energy consumption. The outcome is that this giant nation has quickly become a major GHG emitter. What make the situation worse is the burning down of the rain forest in parts of Indoneasia. 


\section{Figure 12. Energy future for Indonesia}

\section{INDONESIA'S NEW \& RENEWABLE ENERGY TARGET}

New and Renewable Energy

Coal

oil

Natural Gas

Current Situation
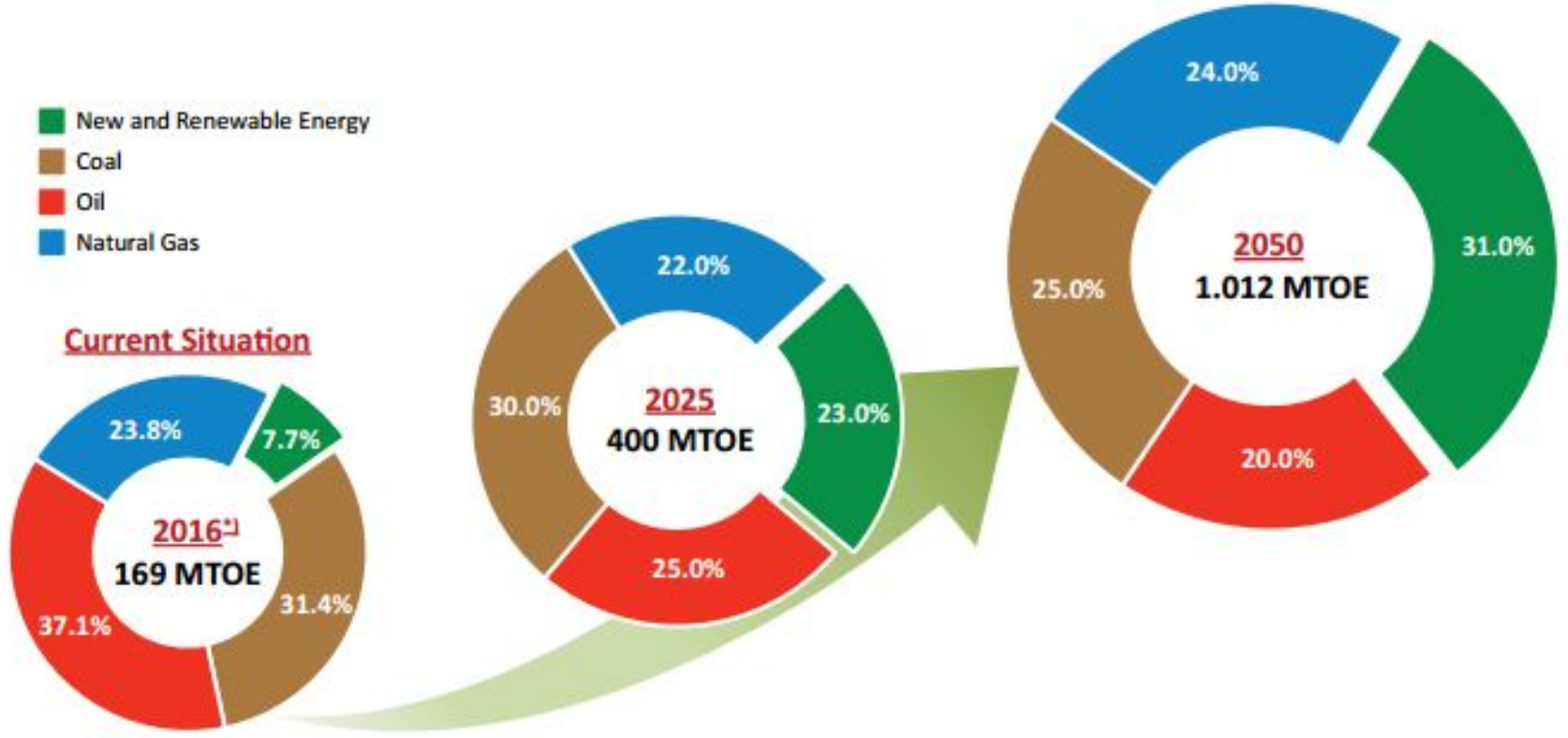

\begin{tabular}{|l|c|c|c|}
\hline & 2016 & 2025 & 2050 \\
\hline NRE Mix & $7.7 \%$ & $23 \%$ & $31 \%$ \\
\hline Energy Supply & $169 \mathrm{MTOE}$ & $400 \mathrm{MTOE}$ & $1.012 \mathrm{MTOE}$ \\
\hline Generation Capacity & $59 \mathrm{GW}$ & $136 \mathrm{GW}$ \\
(NRE $8 \mathrm{GW})$ & $956 \mathrm{kWh}$ & $2.500 \mathrm{kWh}$ & $443 \mathrm{GW}$ \\
Electricity/Capita & $91 \%$ & $\sim 100 \%$ & $7.000 \mathrm{kWh}$ \\
\hline Electrification Rate & (NRE $>165 \mathrm{GW})$ \\
\hline
\end{tabular}

Energy supply hopes in Indonesia are completely unrealistic. No real decarbonisation in sight!

\section{USA}

The US has reduced its $\mathrm{CO} 2$ emissions during the lats years, mainly by a shift to natural gas. Actually, several mature economies have been able to halt the rise of $\mathrm{CO} 2$ emissions, either by more energy efficiency or a shift to natural gas or renewables. Figure 13 captures some features in US energy plans. 
Figure 13. US energy future

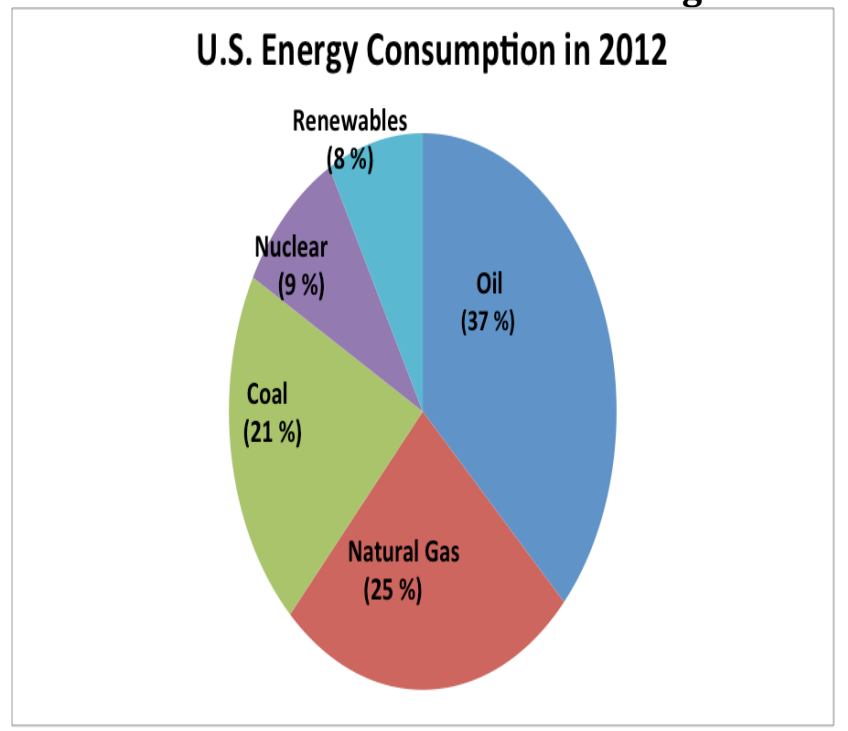

\section{Prediction U.S. Energy Consumption in 2035}

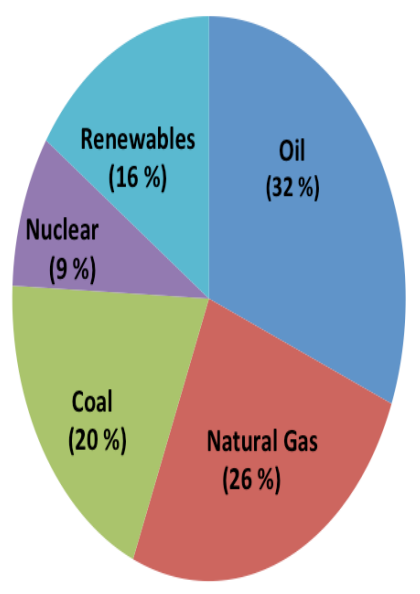

\section{Source: https://www.e-education.psu.edu/egee102/node/1930}

Although the Figure 13 predicts a doubling of renewable energy, the dependency upon fossil fuels, including coal energy, will not bee much reduced. We are talking here about relative numbers, but if the US increases total amount of energy supply, then there may even be more fossil fuels - the fracking business. The reduction in CO2s during recent years seems to be coming at a reduced rate. The hope is for economic growth without energy increases, but we are not there yet. And most countries demand more energy for the future.

\section{China}

China now enters the First World, as it has long passed its "take-off" point in time around 1980 and has pursued a successful "catch-up" policy for a few decades. Its energy consumption, especially fossil fuels, has skyrocketed with GDP, resulting in the largest CO2 emission globally. Figure 14 has a projection for China.

Figure 14. Energy projection for China

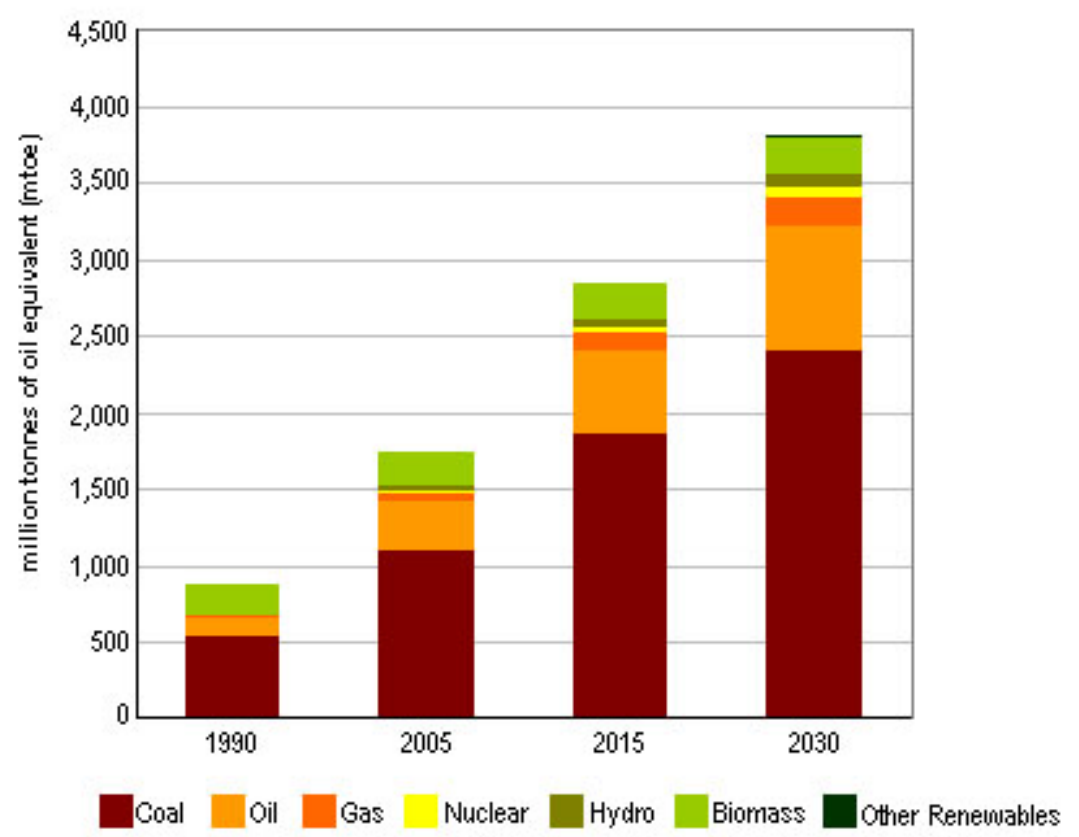

http://www.wrsc.org/attach_image/chinas-projected-energy-growth-fuel 
Decarbonisation does not seem highly probable. Much hope was placed at a recent reduction in CO2s, but water shortages forced China to revert to coal in 2017 with attending augmentation of C02s. China is investing in both renewables and atomic power, but it also plans for large energy increase in the coming decades with lots of energy consuming new projects.

\section{CONCLUSION}

If climate change accelerates, as with abrupt global warming and its dismal feedback lopes, the global coordination by the UNFCCC and IPCC should also change speed. The COP21 project should be implemented with more strength and efficiency, for instance targeting the quick elimination of coal and the building of huge solar power parks in both First World and Thirld Wolrd countries. In poor countrues, before desertification often comes deforestation. It is often stated that land hunger drives deforestation. But equally relevant is the search for energy. We quote from a study on charcoal and deforestation in Africa:

Forests in Zambia are important in supporting life especially in low-income communities both in urban and rural areas. A variety of wood and non-wood forest products are utilised by industries, rural households and urban households in various parts of the country. However, today the forests in the country have been made vulnerable to both man and natural induced disasters. The rate at which forest cover is being lost has increasingly become high such that if this trend is left unchecked time may trigger the complete loss of biodiversity embodied in the Zambian forests. Perhaps the highest loss of forest cover was from 1990 to 2000 with a significant decline of 851,000 ha forest loss per year (FAO 2001). Deforestation as a result of land use change towards agriculture, illegal settlements and Current unsustainable levels of utilisation to mention but a few have contributed to the loss of forest cover in Zambia and the Southern Africa as a whole. The critical question seeking urgent redress is why forests in Zambia are being destroyed more and more.

\section{Source: http://www.fao.org/docrep/ARTICLE/WFC/XII/1022-B1.HTU}

The same findings apply to e.g. Kenya, Sudan and Ethiopia, but also to South Asia.

Time for major energy transformation to save humanity from Hawking inrreversibility is much smaller than earlier believed (Stern, 2007, 2015).

\section{References}

\section{Solar power sources}

Paris 2015: Tracking country climate pledges. Carbon Brief, https://www.carbonbrief.org/paris-2015-tracking-country-climate-pledges

EDGAR v 4.3.2, European Commission, Joint Research Centre (JRC)/PBL Netherlands Environmental Assessment Agency. Emission Database for Global Atmospheric Research (EDGAR), release version 4.3.2. http://edgar.jrc.ec.europe.eu,

CO2 Emission Reduction With Solar http://www.solarmango.com/in/tools/solar-carbon-emission-reduction

\section{GDP sources:}

World Bank national accounts data - data.worldbank.org

OECD National Accounts data files 


\section{GHG and energy sources:}

World Resources Institute CAIT Climate Data Explorer - cait.wri.org

EU Joint Research Centre Emission Database for Global Atmospheric

Research - http://edgar.jrc.ec.europa.eu/overview.php

UN Framework Convention on Climate Change -

http://unfccc.int/ghg_data/ghg_data_unfccc/time_series_annex_i/items/3814.php

International Energy Agency. Paris.

Energy Information Administration. Washington, DC.

BP Energy Outlook 2016.

EU Emissions Database for Global Research EDGAR,

http://edgar.jrc.ec.europa.eu/

World Bank Data Indicators, data.worldbank.org

British Petroleum Statistical Review of World Energy 2016

Environmental Performance Index, Yale University, https://epi.envirocenter.yale. IEA Statistics (C) OECD/IEA 2014 (http://www.iea.org/stats/inde

\section{Literature}

Say, J-B. Treatise on political economy.

https://mises.org/sites/default/files/A\%20Treatise\%20on\%20Political\%20Economy_5.pdf

Ramesh, J. (2015) Green Signals: Ecology, Growth and Democracy in India (2015). Oxford : Oxford University Press.

Stern, N. (2007) The Economics of Climate Change. Oxford: OUP.

Stern, N. (2015) What are we waiting for? Cambridge, MA: MIT Press 